\title{
Police brutality and human rights in Nigeria's democracy: Focus on restoration of man's dignity
}

\section{Christian Chima Chukwu ${ }^{1}, *$, Grace A.-T. Scent ${ }^{2}$ and Obuzor Mezewo Emerinwe ${ }^{3}$}

${ }^{1}$ Department of Sociology. Novena University. Ogume. Delta State. Nigeria. Email: chukwuchidr@gmail.com.

${ }^{2}$ Department of Sociology and Anthropology. Niger Delta University. Wilberforce Island. Nigeria.

${ }^{3}$ Department of Sociology. Faculty of Social Sciences. Rivers State. Nkpolu. Oronworukwo. Port Harcourt. Nigeria.

Abstract. After about twenty years of military rule in Nigeria, Nigerians seemed to have lost the ability to insist on their fundamental human rights. In this vein, any attempt to talk about human rights has been very controversial since the return of democracy in 1991 because the police seem to have taken over the lawlessness of the military as no day passes without a daily occurrence of extra judicial killings, accidental discharge, and other notorious acts against innocent citizens all over the country. Therefore, with police brutality observable in every nook and cranny of the Nigerian society, this study evaluates human rights abuses in Nigeria's democracy with a view to restoring man's dignity that is at lowest ebb today than ever. Since government seems confused on what steps to take to put a stop to the series of abuses of human rights, hypotheses were formulated and literatures related to the variables reviewed. Survey research design was adopted and a total sample of 150 respondents was selected through purposive sampling technique and simple random sampling technique. The hypotheses were tested at 0.05 significant levels and the results of the findings show that all the null hypotheses were rejected and the alternate hypotheses accepted at same significant levels. Among the findings, the study shows that the rule of law in Nigeria has fallen short of the expectations of the citizens. Secondly, the police force has become a stumbling block to the effective administration of Justice and efficient maintenance of law and order as cruelty against citizens are widespread. Furthermore, the sheer disrespect of rules of engagements with imunity by the police not only questions the ability of the government to protect its citizens but also undermines its credibility. Based on the findings, the study concludes that the Nigeria Police Force (NPF) have not only abdicated their constitutional functions, responsibilities and obligations to Nigerians, but are deeply engaged in human rights abuses, bribery, and extortions of money not only from motorists plying our roads but also in our habitudes at the least
Received

January 21, 2020

Accepted

April 14, 2020

Available on line

April 21, 2020

Released

April 30, 2020

Full Text Article

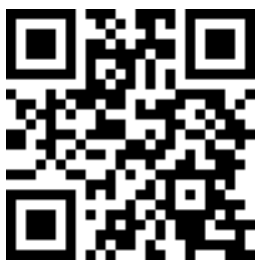

ORCID

(1) 0000-0002-4290-234X Christian Chima Chukwu

D) 0000-0001-8846-6881 Grace A.-T. Scent

D 0000-0001-7836-3977

Obuzor Mezewo

Emerinwe 
opportunity. In this light, the study recommends that as a security organization in a democracy, the Nigeria police should understand that democracy demands that the human personality in its course of development should be allowed to proceed without artificial forces or barricade so long as it actively does not violate the safety and reasonable right of others. In addition, there should be other far-reaching reforms and reorientations necessary to bring Nigeria's policing operations into conformity with constitutional and international human rights standards.

Keywords: Police brutality; Human rights; Nigeria Police; Impunity; Justice; Obligations.

Resumo. Brutalidade policial e direitos humanos na democracia da Nigéria: focando na restauração da dignidade do homem. Após cerca de 20 anos de regime militar na Nigéria, os nigerianos pareciam ter perdido a capacidade de insistir em seus direitos humanos fundamentais. Neste sentido, qualquer tentativa de falar sobre direitos humanos tem sido muito controversa desde o retorno da democracia em 1991, porque a polícia parece ter assumido a ilegalidade das forças armadas, já que nenhum dia passa sem a ocorrência de assassinatos extras-judiciais, quedas acidentais e outros atos notórios contra cidadãos inocentes em todo o país. Portanto, com a brutalidade policial observável em todos os cantos da sociedade nigeriana, este estudo avalia os abusos dos direitos humanos na democracia da Nigéria, com o objetivo de restaurar a dignidade do homem que está hoje em ponto mais baixo do que nunca. Como o governo parece confuso sobre quais medidas tomar para interromper a série de violações dos direitos humanos, foram formuladas hipóteses e relacionadas literaturas às variáveis revisadas. 0 desenho da pesquisa foi adotado e uma amostra total de 150 entrevistados foi selecionada por meio de técnica de amostragem proposital e técnica de amostragem aleatória simples. As hipóteses foram testadas em 0.05 níveis de significâncias e os resultados mostraram que todas as hipóteses nulas foram rejeitadas e as hipóteses alternativas aceitas nos mesmos níveis significativos. Entre as conclusões, o estudo mostra que o estado de direito na Nigéria ficou aquém das expectativas dos cidadãos. Em segundo lugar, a força policial tornou-se um obstáculo à administração eficaz da Justiça e à manutenção eficiente da lei e da ordem, à medida que a crueldade contra os cidadãos é generalizada. Além disso, o simples desrespeito às regras dos compromissos com a imunidade pela polícia não apenas questiona a capacidade do governo de proteger seus cidadãos, mas também prejudica sua credibilidade. Com base nos achados, o estudo conclui que a Força Policial da Nigéria (NPF) não apenas abdicou de suas funções constitucionais, responsabilidades e obrigações para com os nigerianos, mas também está profundamente envolvida em violações de direitos humanos, suborno e extorsões de dinheiro, não apenas de motoristas percorrendo nossas estradas, mas também em nossos hábitos, a menor oportunidade. Sob este 
prisma, o estudo recomenda que, como organização de segurança em uma democracia, a polícia da Nigéria entenda que a democracia exige que a personalidade humana em seu curso de desenvolvimento possa prosseguir sem forças artificiais ou barricadas, desde que ativamente não viole a segurança e o direito razoável de terceiros. Além disso, deve haver outras reformas e reorientações de longo alcance necessárias para adequar as operações policiais da Nigéria aos padrões constitucionais e internacionais de direitos humanos.

Palavras-chave: Brutalidade policial; Direitos humanos; Polícia da Nigéria; Impunidade; Justiça; Obrigações.

\section{Introduction}

Democracy and freedom from oppressive instruments of government are interwoven, and cannot be diametrically opposed to each other without severe consequences. However, in Nigeria, the constitutional provision of equal rights has largely been theoretical because of the viciousness of the police. Despite this, the powers/rights to provide the country with an honest and efficient services vis-à-vis crime prevention, protection of life and property are still vested in the police. This, in the views of scholars, is to deepen democratic principles, ensure the safety of everyone and guarantee human cooperation in a broad-spectrum. Concurring, Groenewald and Peake (2004) aver that the police institution is created to provide the requisite enabling environment for citizens to live and work towards social, economic and political development of the society. Sustaining this assertion, gallantry is expected to be exhibited by the police in the face of serious tragedies like death, deformity (Ibrahim, 2006), but the reality on ground suggests otherwise because there is this joke amongst police officers that runs thus: Protecting Nigeria and ensuring her functionality is not worth the trouble.

This is however not to suggest that there are no patriotic officers who can sacrifice their lives for the uplift of human rights in Nigeria. But that the development of the nation, and by implication, the realization of human rights can only be attained through properly policing the society to create a favourable ambiance for actualization of human rights. Aligning with this assertion, one could contend that the power to protect human rights is independent of external interference in a democracy. But the hostile and vicious attitudes of police officers towards the members of the public since the return to democracy have not been favourably disposed to rejecting the heinous role of the Nigeria's military played for the decades they violated human rights and caused severe political, social, and economic crises in the country. It is in the light of this that Afro beat King, Fela Anikulapo and the Egypt 80 Band, in one of his songs, caricatured the country's military on its abuse of human rights stance which christened "Animal Rights". Years after the release of the hit track, torture and ill treatments and even deaths in police custody are no more news in Nigeria. While it is annoying that from available literatures, the police do not seem to know that detainees have not been convicted of any crime yet, hence deserves some respects; they are merely suspects in respect of whom the presumption of innocence applies. Essentially speaking, detainees' basic rights such as free access to their lawyers, access to family members, medical personnel have not been cancelled by any court of competent jurisdiction as police officers have often alleged.

At this juncture, it is perhaps necessary to state that human rights are inherent in individuals' nature and without which they cannot live as human beings. They are indispensable in the true development of human qualities: intelligence, talents and 
conscience to satisfy spiritual and other needs. The denial of these rights is not only an aberration for individuals and personal tragedy but also creates conditions of social and political unrest. Fundamentally, the absence of the human rights reflects the institutionalization of bad governance in any society. They are based on humankind's increasing demand for a life in which the inherent dignity and worth of each human being is accorded respect and protection. The denial of these rights is not only an individual and personal tragedy but creates conditions of social and political unrest which connotes bad governance in any society.

Successive regimes, most surprisingly, even civilian regimes in democracy have always regarded any human rights issues as very topical, and this tends to generate a lot of controversies. On the other side, is the ever increasing acts of lawlessness by officers of the Nigeria police, their blatant abuse and denial of the fundamental human rights of Nigerians at the least provocation goes to substantiate the claim that the police in Nigeria was first and foremost to guide the governmental interests and as well as the economic needs of colonialism which is exploitation. It was never to improve the lives of Nigerians as most scholars have argued. Studies abound, including media which have accused and found police guilty of brutality including: lawlessness, torture, extra judicial killing, assault, abuse of uniform, deception, sadism, and extreme inefficiency (Amnesty International, 2002; Tamuno et al., 1993). Going by their unrepentant disposition, the sight of police officers anywhere, irrespective of the circumstances, sends fears down the spines of people as arbitrary arrest, unlawful detention, and other forms of threats until family members negotiate payment for their release of their loved ones. While contributing to the infamous saga, Alemika (1999) aptly raises three fundamental questions which have been modified thus: (i) Since the police are expected to be moral as well as law enforcement agent, how can the crusade against corruption succeed if police themselves are strikingly corrupt? (ii) The police have profound powers to guide life, and property of Nigerians, but where such powers are contaminated by corrupt motives, will the powers still be meaningful? Admittedly, police corruption tantamount to extortion, a form of robbery or demand with force, is there any reason why the public will not be threatened by such practices? The most significant source of negative police community relations is corruption, and corrupt motive is also a source of police brutality (Alemika, 1999). In many circumstances, police brutality, Alemika (1999) argues, is a means of coercing individuals to succumb to demands for bribes, and at some other time, it is punishment for not for gratifying them. It is absolutely unfathomable that the Nigeria police has over the years acquired a dubious reputation as a security agency where no justice gets done until money changes hand. While consenting to the observations raised by Alemika (1999), it is disheartening to acknowledge that human rights abuses are generally perpetrated by officers. With this widespread contradiction, one really wonders the raison d'être police is consistently and out-rightly fuelling abuses and becoming enemies to Nigerians. The other side of the coin argues that the Nigeria police force are established by government and granted enormous powers by law and the constitution to take preventive measures against the commission of all crimes in Nigeria; in this sense the law allows them to use such reasonable force as may be necessary for the prevention of crimes, and effect arrests, but at what cost?

Despite the logic, it does appear that the problem of human rights abuses amongst officers of the Nigeria Police has defiled solution. Worrisome as it is, since the return to civil administration in 1999, the nature of governance, particularly as it concerns human rights violations in Nigeria has been inconsistent with world standards despite the practice of democracy. In an attempt to find raisons d'être for police viciousness, we are constrained to ask the following questions: what is the explanation for police brutality? Did the long stay of the military in governance shape the disposition of the police in human rights abuses? Why was refined character not employed as basis for recruitment? 
Whichever, is it justifiable to extort money at road-blocks at the detriment of providing security? How can this lawlessness be corrected? Finally, what extent has police brutality impacted on the psyche of Nigerians? Too many questions one may contend to find the magic portion to ensuring the human rights and the restoration of man's dignity in Nigeria. From the foregoing, this paper attempts to critique Nigeria police and its human rights abuses in order to restore man's dignity in Nigeria's democracy.

\section{Review of related literature}

\section{Emergence and creation of the Nigeria police}

The emergence of the police can be traced back to the era of the mutual pledge system. Mutual pledge system was a fore runner to the institution of Police force in Britain. Under the mutual pledge system, villagers were responsible for their safety as well as protection of their settlements from thieves and marauders. It was a sort of collective responsibility for everybody. Ten families were grouped into collectives, called a tithing, and entrusted with the task of protecting their settlements from thieves and marauders. The tithing was rearranged into a hundred, supervised by one amongst them though appointed by the local noble. The appointee who is considered the first real police officer deals with more serious breaches of the law. With the passage of time, there was a reorganization of the mutual pledge system in such a way that hundreds of families formed shires, an equivalent of local government area of today. Similarly, the head of the shire, known as sheriff was appointed by a king or queen to supervise a certain territory and ensured that law and order was kept. In this arrangement, the sheriff soon began to pursue and apprehend law violators hence the creation of the Office of Justice of Peace in about 1326. In due course, the Justices of peace took on judicial functions in addition to their primary duty as peace keepers. A formal system of security watch developed in which the local constable became the operational assistant to the Justice of the Peace supervising the night watch, investigating offences, serving summons, executing warrants, and securing prisoners. Gradually, the mutual pledge system died-out for the following reasons:

i. What was everybody's duty was nobody's duty;

ii. People no longer had respect for the constables because some of them were illiterates;

iii. There was some reliance on paid night watchmen.

Thereafter, there emerged the industrial revolution which lured thousands from countryside to work in the larger towns. The low wages earned by the swelling population could hardly sustain them and as result, there was increase in crime which heightened the need for formal protection. The development of organic solidarity which replaced mechanical solidarity brought a change in communal social life and a decline in community sense of belonging. In response from established citizens, the government passed statutes creating new protection agency in England. The agency employed three Justices of Peace who employed six able and healthy persons as staffers (constables). Thereafter, law began to be more centralized and professional. In furtherance to this, a protection agency was created through the acts of parliament. With time, the protection agency was re-branded as the first organised Police force in London with members being cloaked in a distinctive uniform and led by two magistrates, who were later given the title of Commissioner.

However, it is instructive to note that in as much as the people wanted the establishment of a protection agency; the institutionalization of a professional, uniformed protection agency was resisted by many people for the simple reason that they feared that an armed protection agency in the hands of the Central Government might threaten their 
freedom. Besides, the people were aware that the professional uniformed protection agency was principally established to protect the rulers rather than them. Despite the resistance of the idea of armed, military-style police on the British soil; it was introduced into Nigeria not necessarily to undermine human rights which were the bane of its rejection, but to protect the colonial masters as well as the interest of the metropolitan (British) economy in whatever form deemed necessary.

Sequel to the stated, the police became a tool to harass, intimidate and employ violence against opponents, and in most situations lynch them. Expounding this assertion, Nwabueze (1992) declares that during the era of regionalism in Nigeria, each region had its own local police. However, he contended that the local police forces in the Northern Nigeria ... were turned into the local arms of the parties in power. As a result, criminal charges against anyone in government were disregarded. The injustice inherent in the regional policing ignited the call for a single police force for the country. However, since the unification, one wonders if a change has occurred between what Nwabueze (1992) queried about and what is occurring in contemporary times where only members of the opposition are being hunted. The subversion of the rule of law and professionalism would have been off the media. But the disruption of campaigns by armed thugs as witnessed in the concluded gubernatorial elections in Kogi and Bayelsa States (Nigeria), where amongst other claims people were beheaded in one of the states in order to snatched election materials, but the burning to death of a woman leader of one of the political parties in inside her private residence will ever remain a horrible commentary in the annals of the elections in Nigeria. While the inactivity of the police remains condemnable, the purported body language or declarations of her allegiance to the federal government is difficult to comprehend. Agreed this is against Article 26 of the ICCPR that provides that all persons are equal before the law and are entitled without any discrimination equal protection before the law. But what do we make of the Police Act that kicks against any undue arrangement with any government or political party in Nigeria? Frustratingly, the body language of the police hierarchy seems to suggest that "failure to support the government is tantamount to rebellion, and therefore, a punishable offense" (Amnesty International, 2002). Disappointing as it may seem, all these aberrations and consequences on human rights are self-evident of the forceful imposition of policing on the Nigerian people by the imperialists.

Undoubtedly, section 194 (1) of the 1999 Constitution of the Federal Republic of Nigeria (Nigeria, 1999) that created the Nigeria Police Force as the National Police with exclusive jurisdiction throughout the country was silent on profiling the character of recruits; there was no background check on who and who must be recruited. Obviously, that seems to be the herculean task as all kinds of individuals have been enrolled into the force. Unfortunately, no one seems to view it as a handicap. Surprisingly however, the colonial masters accentuated on refined character as bedrock for recruitment in their land. But in Nigeria, the hypocritical stance of the colonial policing is vexatious. As a result, the police have been epitomizing darkness, brutality, deceit, recklessness and remain the sole proponent of uncompleted investigations. For example, the assassination of Chief Dikibo, a chieftain of Peoples Democratic Party in Rivers State and Chief Bola Ige, the Minister for Justice and Attorney General are still being investigated after about sixteen years as no person yet has been convicted for these high profile murders, even when there are possible clues (Coker and George-Geny, 2014). More worrisome, according to Coker and George-Geny (2014), is the allegation that many of the suspects have been rewarded with electoral and executive appointments. From the foregoing one could easily assert that there is a positive correlation between Nwabueze's earlier assertions that criminal charges levied against persons in corridors of power are unseen (Nwabueze, 1992) and the prevailing circumstances nowadays. 
Of all follies, we have often argued that, there is none greater than reforming the Nigeria police force because her history since inception has been not only of exploitation and brutality, but also protecting the bourgeoisie as it is nowadays. Accordingly, the exploitation and brutality of the Nigeria police remains the reason many a person in government still prefer to keep the force as it is, to preserve the status quo, and thus, see reformers as idealists who have lost touch with reality. While it is lamentable that officers genuflect to perpetual adoration of wealth, murals of dictators, quack-pastors and occultists (who they now body-guard), political thugs, narcotics smugglers, murderers, and religious bigots, can the Nigeria Police still attain greatness and position of respectability? The pains, humiliations, frustrations and disappointments that have tried many souls whose loved ones have continuously been brutally murdered through "accidental charges" by police because they obstructed justice are troubling. At this juncture, we could be tempted to assert that the interpretation of human rights violations by the Nigeria police could be liken to Ayi Kwei Armah's satirical novel: 'The beautyful ones are not yet born' because no one has yet succeeded in laying bare the total pattern of that novel (Armah, 1968). Likewise, no one too has been able to understand the Nigeria police in its entirety. Unfortunately, no one is really hot and bothered about this high level of police brutality being the masterminds by a few individuals whose deception, falsehood, greed and demonic influence is insulating all nooks and crannies of the Nigerian society. And as the year gradually rolls by, so overwhelming is the abuse of human rights that one is forced to pause a moment. Let one's thoughts on the Nigerian society wander while one stands aside and ponder over the brutality of the Police in Nigeria (PIN), otherwise called the Nigeria Police Force (NPF). While disappointedly, the force suffer from identity crises and also have the odd reputation of snuffing out life from innocent Nigerians at the least provocation, it is undisputable that the police epitomize darkness, brutality, deceit, recklessness and remain the sole proponent of uncompleted investigations. This uncompleted investigation of several deaths has become very ravenous and devastating to an extent that officers have become leprous, both in colour and content. Contradictorily, the police insist that Nigerian citizens are their friends even when no one of us one is safe in their custody. Basically, it has been argued in some circles that until the Police in Nigeria (PIN) become a truly Nigeria Police Force, (NPF) nothing whatsoever can be done to better her corrupt image. For many, the police are walking corpses.

Admittedly, there has been too much of oppression and brutal display of wickedness by the powerful rich against the poor and needy. In fact, the biting economic situation has reduced Nigerians to either beggars, destitute or prostitutes. The people have gone from bad to worse with virtually every succeeding administration. The people have never had a genuine and truly Nigeria police force that has ever put the national interest over and above parochial, personal and sectional interest. Regrettably, even today, there is nothing in the horizon to suggest any radical departure from the status-quo-ante; because human right abuses are waxing stronger and calling the shots. The Nigeria police have been so much been mismanaged in all spheres of protecting human rights especially at the least provocations that one is tempted to ask the underneath question.

Does a government really possess superior wisdom to those outside it? There may be some debates here but one cannot be persuaded to accept that an individual or government as a group of individuals possesses superior wisdom. A thousand flowers, as the Chinese are wont to say, should blossom and a thousand thought should contend and so, one therefore believes that even a madman has an antidote to usher in a new beginning for the Nigeria police. Police force that is not in a hurry to collapse on itself should not disallow any mad man to make his prescriptions because there may be some untested and unknown wisdom in him. Really, general insanity could be diagnosed for a police force that abhors criticisms and claims to have superior wisdom to those outside it and it is only a mad man who will pray to identify with such an insane police force. In spite of this, there 
are still voices that claim the Nigeria police possess that power and authority to right all wrongs against human rights abuse for the restoration of sanity, discipline, morality and dignity of man in the society.

\title{
Universal Declaration on Human Rights and the Nigerian Society
}

As a universal concept, human rights are inalienable, and indivisible, whether civil or political rights including the right to life, equality before the law and freedom of expression; or as collective rights, they are interrelated and interdependent. From the Magna Carta Declaration in 1215, human rights have gained greater acknowledgments world-wide. Concurring, the widespread acceptance of the importance of human rights gets further boost in the preamble to the Universal Declaration of Human Rights adopted on December 10th, 1948. As a result, numerous international human rights conventions, declarations, and resolutions are in agreement with the tenets of the Universal Declaration on Human Rights. In furtherance to this, Akinbola (2005) emphasizes that, "recognition of the inherent dignity and of the equal and inalienable rights of all members of the human family is the foundation of freedom, justice and peace in the world". However, it is imperative to recognize that the promulgation of these rights is not binding on any country, but they serve as a standard of concern for people and form the basis of many modern national constitutions. Although they are defined first as absolute moral claims or entitlements to life, liberty, and property (John Locke, 1632-1704), the best-known expression of human rights is in the Virginia Declaration of Rights in 1776 which proclaims that

\begin{abstract}
All men are by nature equally free and independent and have certain inherent rights, of which, when they enter a state of society, they cannot, by any compact, deprive or divest their posterity.
\end{abstract}

The principle applies to everyone in relation to all human rights and freedoms and it prohibits discrimination on all fronts. As it were, the system of non-discrimination is complemented by the principle of equality, as stated in Article 1 of the Universal Declaration on Human Rights, "All human beings are born free and equal in dignity and rights." What is more, Akinbola (2005) observes:

\begin{abstract}
In concrete terms, human rights refer to how legal system, the state and its various agencies, and other persons, respect and protect the basic rights and freedoms of each citizen. This is characteristically ensured within the body of laws and the constitution governing the country, through the provision of a set of instruments and status that guarantee the respect and integrity of human beings irrespective of race, creed, sex, ethnicity and economic status (Akinbola, 2005, p. 63).
\end{abstract}

Essentially, whenever we speak of human rights, we simply mean those enforceable rights such as freedom of speech, free assembly, the right to vote, freedom of association, among others, but in reality, the power to determine who is worthy to enjoy human rights as long as one pays some bribes rests with the police. While this is condemnable, it is important to stress that human rights are the cornerstone of a free society. While admitting that some of these sections of Human Rights presented hereof are fundamental to ensuring the Nigeria police are abreast these rights etched on marbles, it is also central for the police to comprehend that liberty amongst Nigerians are nonnegotiable.

\section{Police brutality and its implications}

Undoubtedly, the police are granted enormous powers by law and the constitution to take preventive measures against the commission of all crimes in Nigeria. Under this 
premise, the law allows them to use such reasonable force as may be necessary for the prevention of crimes. But in the exercise of this authority, there have been many instances of inexcusable killing of guiltless victims by officers of the Nigeria police. This is particularly executed by junior officers who do not act single-handedly or on their own accord. According to verifiable evidence senior police officers are deeply involved in these brutalities. Regrettably, it is upsetting to observe that police management routinely frustrates any efforts to seek redress or justice by injured victims or their families by reassigning the officers responsible for the crime (Alemika, 1993). For example, in buttressing more of police brutality, the case of Chika Elekwachi, a pregnant married woman in Lagos who refused to be identified as a prostitute, and consequently led to being beaten mercilessly by the police to the extent of losing consciousness and going into brutality-induced premature labour for a baby that later died cannot be ignored. According to human rights watch (Human Rights, 2009), Chika's vehicle was obstructed by a bus; thereafter, one of the three policemen in the said bus came out, pointed a gun at her and ordered her to park. To this, Human Rights Watch (2009) writes:

Occurrences of police brutality of citizens, such as the Chika case, are worrisome and indicative of the indiscipline, impropriety and resultant disappointment in the police. Beating up a married and pregnant woman and stripping her naked because she took an exception to being called a prostitute is a display of insanity and indiscretion. The incident is a misdemeanor.' and we are pained that police brutality is on the rise despite the pledged commitment of top echelon of the police leadership to renew professionalism in the Force (Human Rights Watch, 2009).

It is unthinkable that a pregnant woman could be an object of cruelty. The incidence, extent and pattern of police abuse of rights of citizens in the society as earlier observed are hinged on the status of one involved. Cases of police brutality abounds. The case of Chika is one too many. Among other indictments, the organization said the police detain people to extort money or force a confession out of them. Obviously, some of the torture techniques employed in order to extract confession or extort gratification (Alemika, 1993) mirror a dysfunctional police system that operates in the country. More so, it is obvious from the foregoing that the report by the Open Society Justice Initiative (2011) against the police is not only a shocker, but an undisputable fact. According to the report, bribes are demanded from motorists at roadblocks with reckless abandon. At its worst, the report alleges the police massage Chemical Mace and hot chili pepper into the genitals of those it arrests in order to draw out dubious confessions to use as an excuse to summarily execute those they describe as "armed robbers." In addition, the average police officer on the streets of Nigeria is, most often, armed with horse whip and many of them show considerable enthusiasm in using it on innocent passers-by without provocation. The Report further holds that those who get away with merely being horsewhipped are considered lucky. Many others fare much worse. Writing earlier, Odinkalu(2005) asserts that human safety and security are indeed human rights because they have a value of their own. Undoubtedly, he argues that the state has overriding influence in the security sector and as a result, the legitimacy and right of the people can only be sustained to the extent to which it can guarantee the protection of life and property of its citizens.

\section{Theoretical framework}

\section{The Marxist Conflict Theory}

The conflict theory propounded by Karl Marx (1818-1883) is employed in this paper as its theoretical haven. The theoretical postulations provide a materialist interpretation of history, a critical stance against existing social arrangements, and 
advocate a reform to enthrone the rights of the proletariats (commoners), particularly in Nigeria where this study stems from. Marx argues vociferously, that the materialist view of history starts from the premise that the most important determinant of social life is the labour people are doing, especially work that results in provision of the basic necessities of life, food, clothing and shelter (Marx, 1971), but queried the abuses the proletariats are subjected by the bourgeoisie (owners of means of production). It is very essential to assert that these vicious abuses, including the threat to life, against the powerless contravened all agreements negotiated for safeguarding human rights from different International Human Rights Conferences, including the African Charter of Human and People's Right signed in 1981 (and which became effective in 1986).

Marxist perspectives view power as being concentrated in the hands of a minority in society and which is employed to harass, intimidate and exploit the powerless. By explanation, successive governments in Nigeria have different interests from the ruled (powerless), hence the abuses and dehumanization of the peoples' dignity. The concentration of power in the hands of those who have economic control creates divisions within society. Elucidating further, Marx maintains that the history of all hitherto existing society is the history of class struggles, and that the state serves the dominant classes in society. In this vein, Marx sees the entrenched economic exploitation leading directly to political oppression, and turning the ruled (powerless) into servants of their socioeconomic interests.

Substantiating, Marx argues that the abuse and denial of human rights always serve capitalist interests by pacifying intellectuals, paid directly or indirectly by government to justify and rationalize the existing human rights abuses while majority of the oppressed population is left in the underground of marginalization to mourn their subjugated status as people who have no choice but to accept their fate. Clearly, Marx may have been a prophet to have foreseen the entrenched economic exploitation leading directly to abuses of human rights, as government and all its agencies(as in Nigeria) suppress human rights using governmental directive to justify their cruelty against the people when he was writing.. For example, the police having declared through her body language allegiance to the central government against the statutorily mandate establishing it, majority of the populace have become servants of oppressive interests against their will. In this unholy union, police power, for instance, have continuously been used to oppress and display wickedness as demanded by the powerful rich against the citizenry. As it stands today, the biting economic situation has reduced Nigerians to beggars. The people are dehumanized than ever before with virtually every succeeding administration becoming hostile and cruel to their rights. Essentially, the people have never had a genuine and truly Nigeria police force that has ever put the national interest over and above parochial, personal and sectional interest. Regrettably, even today, there is nothing in the horizon to suggest any radical departure from the status-quo-ante; because human right abuses are waxing stronger and calling the shots.

Conclusively, since the dominant ideology in a capitalist society like Nigeria is that of the ruling class, the socio-economic relations of production are under their control, therefore they reproduce and perpetuate the socio-economic class structure that has continued to maintain the imposed policing system that, after six decades of independence, still remains exploitative and abuser of human rights.

The relevance of this theory to this paper rests on the fact that the dark spots of a leopard cannot be washed away by rain; the exploitative ideology inherent in Nigeria police points to a system of governance that regenerates and perpetuates the interests of the dominant (and bourgeois) class, while uncooperatively refusing to deliver to the citizens their fundamental human rights to restore their human dignity. 


\section{Methods}

This work adopted the survey research design. Survey design, according to Denga (1986) is that which is directed towards determining the nature of a situation as it exists at the time of investigation. It is also a process where large small samples are drawn from a given population. The researcher settled for this design because of its preoccupation in describing and establishing relationships among variables. Apart from this, the design is also concerned with gathering of data at a particular point in time with the intention of knowing the nature of already existing conditions, or identifying standards against which these conditions can be compared with other specific events. To achieve the purpose of this study, three hypotheses were formulated to guide the study and the population area was given equal and independent opportunity to be selected in the study. The questionnaire, the major instrument used for data collection. One hundred and fifty (150) respondents were selected as sample for the study. Chi square $\left(\mathrm{X}^{2}\right)$ statistical analysis was adopted to test the hypotheses at 0.05 level of significance.

The formula for chi-square $\left(\mathrm{X}^{2}\right)$ is computed using the formula,

Fo $=$ Observed frequencies; Fe $=$ Expected frequencies $; \mathrm{Df}=$ Degree of freedom; $\mathrm{r}=\mathrm{Row} ; \mathrm{c}$ $=$ Column

$$
\text { Df }=(r-1)(c-1)
$$

\section{Test of hypotheses}

$\mathbf{H}_{\mathbf{0}}$ : There is no significant relationship between the imposition of a policing system and human rights abuses in Nigeria

$\mathbf{H}_{1:}$ There is a significant relationship between the imposition of a policing system and human rights abuses in Nigeria

Table 1. The Chi Square $\left(X^{2}\right)$ statistical analysis for hypothesis 1 is computed showing the relationship between the imposition of a policing system and human rights abuses in Nigeria.

\begin{tabular}{|l|c|c|c|c|c|}
\hline \multicolumn{1}{|c|}{ Responses } & Fo & Fe & Fo-Fe & (Fo-Fe) $^{2}$ & $\frac{\mathbf{F o}^{2}-\mathbf{F o}^{2}}{\mathbf{F e}}$ \\
\hline Yes & 109 & 75 & 34 & 1156 & 15.41 \\
\hline No & 41 & 75 & -34 & 1156 & 15.41 \\
\hline$\sum=$ & 150 & 150 & - & - & 30.82 \\
\hline
\end{tabular}

$\mathrm{P}<0.01$

Calculated $\mathrm{X}^{2}=30.82$

Degree of freedom $=(\mathrm{r}-1)(\mathrm{C}-1)$

$=(2-1)(5-1)$

$=(1)(4)=4$

Degree of freedom, 4; significant level, 0.01 ; table value, 12.592; calculated $\mathrm{X}^{2}=30.82$.

\section{Results}

The result in the data analysis as presented Table 1 showed that at 0.05 significant level, the value of the calculated $\mathrm{X}^{2}=30.82$ goes beyond the .01 value of 12.59 at 4 degree of freedom. Thus, we reject the null hypothesis and accept alternate hypothesis, there is a significant relationship between the imposition of a policing system and human rights abuses in Nigeria. 


\section{Test of hypothesis two}

$\mathbf{H}_{\mathbf{0}}$ : There is no significant relationship between poor recruitment and inadequate training of officers and human rights abuses.

$\mathbf{H}_{\mathbf{1}}$ : There is a significant relationship between poor recruitment and inadequate training of officers and human rights abuses

Table 2. The Chi Square $\left(\mathrm{X}^{2}\right)$ statistical analysis for hypothesis 2 is computed showing the relationship between poor recruitment and inadequate training of officers and human rights abuses.

\begin{tabular}{|c|c|c|c|c|c|}
\hline Responses & Fo & $\mathbf{F e}$ & Fo-Fe & $(\mathrm{Fo}-\mathrm{Fe})^{2}$ & $\frac{F_{0}-F^{2}}{F e}$ \\
\hline Yes & 111 & 75 & 36 & 1296 & 17.28 \\
\hline No & 39 & 75 & -36 & 1296 & 17.28 \\
\hline$\sum=$ & 150 & 150 & - & - & 34.56 \\
\hline
\end{tabular}

$\mathrm{P}<0.01$

Calculated $\mathrm{X}^{2}=34.56$

Degree of freedom $=4$, value 13.28

Degree of freedom, 4; significant level, 0.01; table value, 13.28; calculated $\mathrm{X}^{2}=34.56$

\section{Results}

From the analysis of data obtained in hypothesis two, the relationship is very significant as the value of the calculated $X^{2}=34.56$ is greater than the value of .01 level at 4 degree of freedom which is 13.28 . Thus, we reject the null hypothesis and accept the alternate hypothesis. There is a significance relationship between poor recruitment and inadequate training of officers and human rights abuses

\section{Test of hypothesis three} rights abuses

$\mathbf{H}_{\mathbf{0}}$ : There is no significant relationship between police corruption and human abuses.

$\mathbf{H}_{1}$ : There is a significant relationship between police corruption and human rights

Table 3. The Chi Square $\left(\mathrm{X}^{2}\right)$ statistical analysis for hypothesis 3 is computed showing the relationship between police corruption and human rights abuses.

\begin{tabular}{|c|c|c|c|c|c|}
\hline Responses & Fo & Fe & Fo-Fe & $(\mathbf{F o}-\mathbf{F e})^{\mathbf{2}}$ & $\frac{\mathbf{F o}^{-\mathbf{F e}^{2}}}{\mathbf{F e}}$ \\
\hline Yes & 100 & 75 & 25 & 625 & 8.33 \\
\hline No & 44 & 75 & -25 & 625 & 8.33 \\
\hline$\sum=$ & 150 & 150 & & & 16.66 \\
\hline
\end{tabular}

$\mathrm{P}<0.01$

Calculated $\mathrm{X}^{2}=16.66$

Degree of freedom $=4$, value 13.28

Degree of freedom, 4; significant level, 0.01; table value, 13.28; calculated $\mathrm{X}^{2}=16.66$ 


\section{Results}

From the results obtained, at 0.1 level, there is significant relationship between police corruption and human rights abuses as the value of the calculated $\mathrm{X}^{2}=16.66$ is greater than the value of .01 at the 4 degrees of freedom level which is 13.28. Thus, we reject the null hypothesis and accept the alternate hypothesis. By implication, there is a significant relationship between police corruption and human rights abuses.

\section{Findings}

From the results obtained in hypothesis one, there is a significant relationship between the imposition of policing and Human Rights abuses in Nigeria. Colonial policing emphasized the protection of the lives and property of the European merchants, other businessmen, and Christian missionaries (Ojomo, 2010). The colonial ruling class subjugated the indigenous people, and imposed a careful surveillance over them in order to forestall any popular rebellion, created an obsession with the policing of public order. Succinctly put, colonial police in Nigeria emphasized impunity and riot suppression which run contrarily to human rights in maintaining law-and-order. According to Ahire (1991), the ruling class in the then colonial Nigeria was foreign and illegitimate one that dominated and exploited the indigenous people in the interest of its own metropolitan (British) economy. Nearly six decades after independence, nothing seems to have changed as respondent's personal experience of brutality in the hands of the police reveals that, very only few respondents have not been assaulted by the police. While it is worrisome to observe that the practice of being slapped, kicked, beaten and threatened which were features of colonial policing are still prevalent in contemporary Nigerian society, it important to acknowledge that these barbaric acts against Nigerians are degrading treatment prohibited by the constitution.

Results from the second hypothesis shows that there is a significant relationship between training of police officers and the flouting of fundamental human rights. With the absence of a refined character as a basic criterion for recruitment into the force, the attitude, mentality and inadequate training of officers from the colonial era to date have made them violate human rights with grave impunity. Furthermore, it is generally agreed by respondents that the recruitment exercise has continued to be fraudulent as it is alleged that people seeking to join the Police offer bribes to getting enlisted into the Nigeria police force training colleges across the country.. Accordingly, this has led to the recruitment of awkward officers, and perhaps; criminals into the police. Corroborating this observation, Alemika(1988) states that the traditions of civility, efficiency, and submission to the rule of law that constituted the bedrock of the British police system were not emphasized in the creation of Nigeria police. As a result, most police officers have not been satisfactorily trained to carry out the primary task of preventing, detecting and prosecuting crime. Besides, the poor budgetary allocations and lack of manpower to groom not only in theoretical aspects of policing but practical aspects have raised the concerns of the public over the incidence of police brutality as no day passes without a daily occurrence of unjustified killings of Nigerians. The shooting to death of six innocent traders in June 2005 by police officers at a night patrol will remain a sad commentary in the annals of policing in Nigeria.

Finally, results from the third hypothesis show that there is a significant relationship between police corruption and human rights abuses. From the in-depth interviews, senior officers at the top massively exploit and maltreat those in the lower cadre. At times, a certain percentage is deducted from their paltry salary of junior officers for flimsy excuses. Thus, in an attempt to recoup their unjustifiable loss from senior officers, the words: honesty and trust seem to be lacking in almost all relationships the police officers have had with the public. Basically, one major aspect of police corruption is the extortion of money at road-blocks with little or no attempt to hide the collection of 
money from motorists plying the roads. According to respondents, the roadblock extortion is the easiest and most lucrative means of corrupt enrichment by the officers ranging from constable to whoever leads the patrol team. This misdemeanor has been so deep-rooted that every senior police officer from the rank of Deputy Superintendent (DSP) to ICP is associated with the extortion contra-culture. More so, on daily basis officers frequently threaten victims and commit human rights abuses through standardized "toll" at the roadblocks where no attempt is made to hide their collection of money exposing the near total lack of will on the part of government authorities to hold them accountable.

\section{Conclusion and recommendations}

This paper has concentrated on police brutality and human rights abuse in Nigeria with a view to restoring the dignity of man's dignity in a democracy. In so doing, policing needs to be reformed in Nigeria. The change advocated is one that is bent to improve the standard, reliability, consistency, and responsiveness of the service to Nigerians. There is also need to ensure that the police do their work effectively and ensure that the issues of mistrust, fear and viciousness are done away with in the psyche of Nigerians when relating with police officers. Essentially, the police in Nigeria need to ensure that their conduct is governed by a set of the right rules and principles and their conduct based on legality. Police work demands a high degree of ethical professionalism due to the fact that the community does not expect the police to break the law. It is therefore imperative that the senior ranks must set a good example and put adequate measures to deal with unethical behaviour in the force. The challenge to the state is to provide the means which will enable police officers and support staff to work better and to do their job free from complicated and time consuming procedures, unnecessary to achieve results or to protect basic rights. According to Makwerere et al. (2012), it is time to focus on preventing crime and protecting the victims, and to place the weight of society behind this drive to reform the police because sustaining the denial of human rights in any society is a structural cause of high intensity conflict.

Thus, for human rights abuses by the police to be stopped or brought to its barest level, the following recommendations have been proffered:

1. In Nigeria, the misuse of powers by the police manifested in police brutality of innocent citizens is worrisome. Therefore, all mass media and civil society organizations, including religious groups should encourage their members to speak out against human rights abuses and also demand for reorientation towards adequate reorganization that will uphold and respect for human rights and in the end restore man's dignity.

2. The growing concern by generality of the Nigerian public over the incidence of police brutality has clearly shown that no day passes without a daily occurrence of killings of innocent citizens unjustifiably. In an attempt to checkmate this anomaly, government should set up external monitoring bodies to help check the excesses of police officers, especially those on the road. More so, the recruitment exercises should be conducted diligently with techniques that will test the level of honesty or dishonesty of potential future policemen.

3. The police should partner with the local neighbourhoods to effectively establish an efficient community policing to enhance security, and also create a disciplined and law-abiding citizenry imbued with the right values and attitude towards safeguarding life and property in the country. By extension, public awareness, seminars, et cetera should be constantly and regularly conducted to promote the rule of law and accountability and also fight against impunity.

4. Corrupt practices among security operatives should be seriously tackled. To this, policies on police corruption should be documented and made available to the public stating their punishment for different levels and degrees of offences and 
corruption. In addition, a reward system should be developing to honor and reward deserving police offices for gallantry especially with the daily hazards they face while on duty.

\section{Conflicts of interest}

Authors declare that they have no conflict of interests.

\section{References}

Ahire, P. T. Imperial policing: The emergence and role of the police in colonial Nigeria. Philadelphia: Open University Press, 1991.

Akinbola, B. R. Globalization of human rights and the Nigeria Legal system: problems and prospects. In: Olu-Olu, O. Perspectives in globalization and Africa development. Lagos: 2005.

Alemika, E. E. O. Criminology, criminal justice and the philosophy of policing. In: Tamuno, T. N.: Bashir, I. L; Alemika, E. E. O.; Akano, A. O. (Eds.). Policing Nigeria: Past, present and future. Lagos: Nigeria Police Force and Malthouse, 1993. p. 30-78,

Alemika, E. E. O. Police community relations in Nigeria: What went wrong? Proceeding of the Seminar on Role and Function of the Police in a Post Military Era, Centre for Law Enforcement Education (CLEEN) and the National Human Rights Commission, Abuja, 1999.

Alemika, E. E. O. Policing and perceptions of police in Nigeria. Police Studies, v. 11, no. 4, p. 161-176, 1998.

Armah, A. K. The beautyful ones are not yet born. Boston: Houghton Mifflin, 1968.

Coker, M. A.; George-Genyi, M. E. Bad governance: The bane of peace, security and sustainable development of Nigeria. International Journal of Development and Sustainability, v. 3, no. 5, p. 1121-1146, 2004.

Groenewald, H.; Peake, G. Police reform through community-based policing: Philosophy and guidelines for implementation. Policy Paper, sept. 2004. Available from: <https://www.ipinst.org/2004/09/police-reform-through-community-based-policingphilosophy-and-guidelines-for-implementation>. Accessed on: Jan. 12, 2020.

Human Rights Watch. Human Rights Watch Report 2009. Available from: <http://www.hrw.org/reports/2009/Nigeria0402.pdf>. Accessed on: Jan. 12, 2020.

Ibrahim, A. Police corruption and the state: Prevalence and consequences. Global Journal of Arts Humanities and Social Sciences, v. 4, no. 9, p. 32-42, 2006.

Makwerere, D.; Chinzete, G. T.; Musorowegomo, C. Human rights and policing: A case study of Zimbabwe. International Journal of Humanities and Social Science, v. 2, no. 17, p. 129-138, 2012.

Nigeria. The Constitution of the Federal Republic of Nigeria 1999. Lagos: Government Press, 2001.

Nigeria: Amnesty International. 2002. Available from: <http://amnesty.org>. Accessed on: Jan. 12, 2020.

Nwabueze, B. O. Military rule and constitutionalism. Enugu: Spectrum, 1992. 
Odinkalu, C. A. When did the police become (Y)our friend? Changing roles of civil society in promoting safety and security in Nigeria. In: Alemika E. E. O.; Chukwuma, I. C. (Eds.). Crime and policing in Nigeria: Challenges and options. Lagos: CLEEN Foundation, 2005. p. 35-48.

Ojomo, A. Historical reflections on internal control systems in the Nigerian Police Force. Lagos: CLEEN Foundation, 2010.

Tamuno, T. N.; Bashir, I. L.; Alemika, E. O.; Akano, A. O. (Eds.). Policising Nigeria: Past, present, and future. Lagos: Nigeria Police Force and Malthouse, 1993.

License information: This is an open-access article distributed under the terms of the Creative Commons Attribution License, which permits unrestricted use, distribution, and reproduction in any medium, provided the original work is properly cited. 